\title{
3 The Land and the People
}

\section{I THE LAND: PAST A N D PRESENT}

The preceding chapter 2 has dealt with the most important aspects of Bronze Age foundations on which the first millennium BC societies of southeast Italy arose. The basic aim of that chapter was to give a background to the following chapters 4-7: it offered a very generalized and necessarily incomplete picture of the societies of southeast Italy that preceded the societies of the first millennium BC. The present chapter gives a short account of the variety of landscapes in which these pre-Roman societies flourished. It introduces the names of the geographical elements as, for instance, rivers and mountain ridges that feature in the following chapters. Furthermore, the names are presented of both the districts and the groups of people that reportedly lived in these landscape units in the period under discussion. The aim of this chapter, therefore, is to supply generic information on the geographical setting and introduce terms and names that are current in the archaeology of region under discussion. These will frequently pop up in the following chapters.

Southeast Italy consists of a series of interconnected districts with vastly different natural landscapes. These range from steep, $1700 \mathrm{~m}$ high mountains to large alluvial plains only slightly above sea level. The area discussed in this book corresponds by and large with the present-day Italian regions of Basilicata and Apulia and the northern Cosenza province of the present-day region of Calabria (fig. 3.1). These are separated from other Mediterranean regions by high mountains and deep seas. To the west and the north southeastern Italy is fenced off from Campania by the inhospitable southern Apennines, the passes here being between 600 and $1.000 \mathrm{~m}$ above sea level. In the northeast the foothills of the Apennines come close to the coast. Here the Gargáno peninsula (the spur of the Italian boot) rising up to $1,500 \mathrm{~m}$ high projects into the Adriatic Sea. At this point, however, there is no real barrier between north-Apulia and the adjoining central-Italian Molise region. A low ridge gives access from the latter region to the great plain of north-Apulia. On its east and south sides, southeast Italy is completely surrounded by seas: the Adriatic Sea, the Ionian Sea and the Gulf of Táranto. This gulf penetrates into the Apennine peninsula. Therefore, the sea is never far away. It was, and continues to be a very important factor in the geography of the region.

The inhabitants of pre-Roman southern Italy adapted themselves to these varied environments and tried to adapt these landscapes to their own purposes. This large region contains two large and fertile alluvial plains. One of these is the plain of the rivers Crati and Coscíle in the northern part of present-day Calabria, often indicated in archaeological reports as 'the Sibarítide' (i.e., the area around Sybaris). The plain is surrounded by high mountains on nearly all sides, being open to the sea only towards the east. Most of the sites are on the foothills and lower mountains of the Sila and Pollino massifs that surround the plain. The second, even larger plain is situated in the northern part of the present-day region of Puglia (fig. 3.2). This district is aptly called 'the Tavoliere'.' It is surrounded on nearly all sides by mountains and ridges, except to the east (Adriatic Sea, Gulf of Manfredónia). A series of streams rising in the foothills of the Apennines intersect the plain from southwest to northeast

1 From the Italian tavola (table; i.e. flat as a tabletop). 


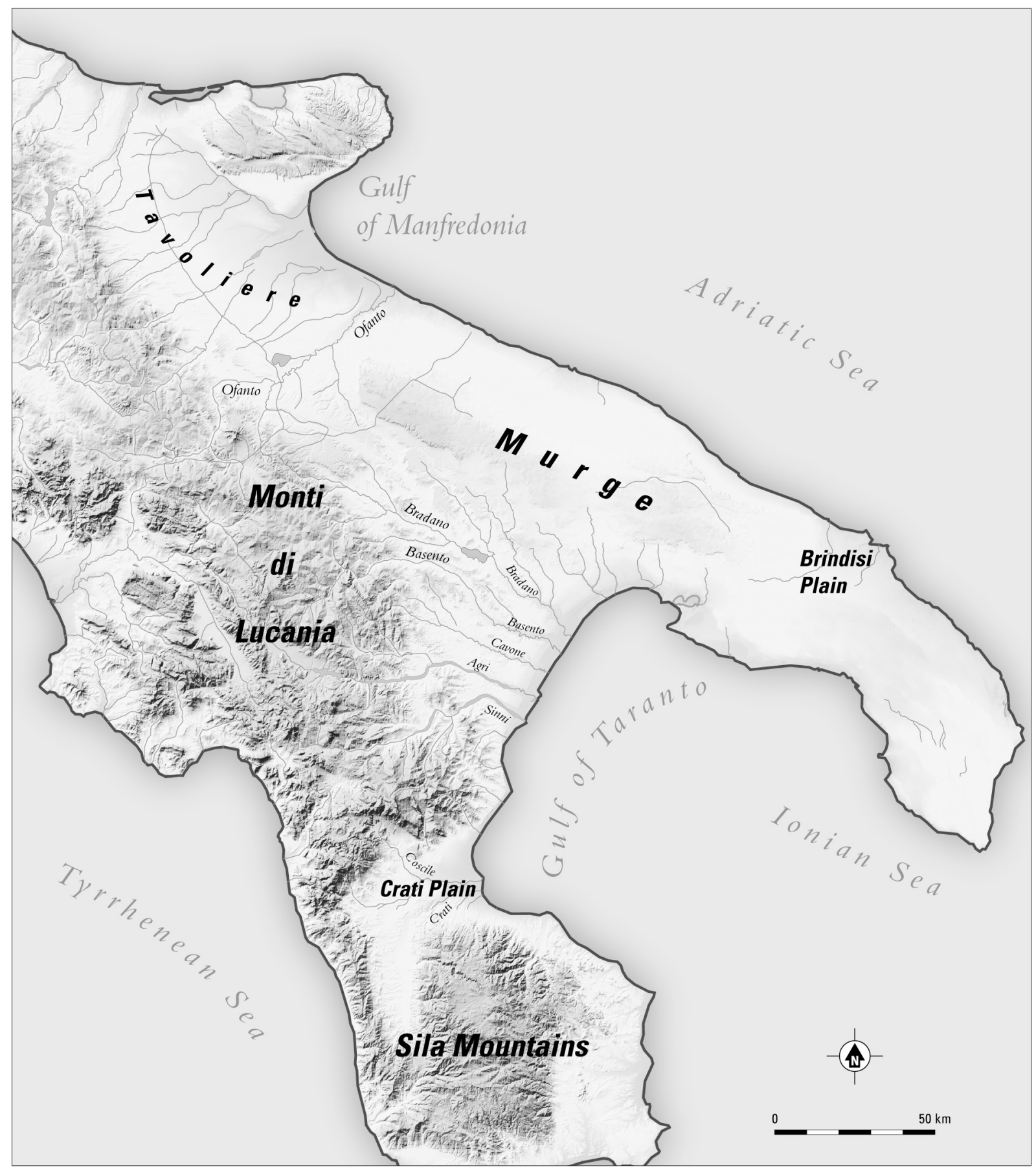

Fig. 3.1. Southeast Italy: mountains, plains, rivers and seas.

and discharge into the lagoons on the Gulf of Manfredónia, south of the Gargáno peninsula. ${ }^{2}$ Whilst the heavy alluvial soils flanking the watercourses were unfit for agriculture in ancient times (but they were good grazing areas), the slightly raised areas between the streams have light arable soils consisting of clayey sands. These areas were preferred for human settlement by the pre-Roman populations. Smaller plains with calcareous soils consisting of fertile clayey sands are found in the Salento peninsula

2 These are the rivulets Candelaro, Celone, Cervaro and

Carapelle (see fig. 3.1). 
(the heel of the Italian boot). Here the flat areas around the present-day towns of Taranto, Brindisi and Lecce were densely inhabited in the first millennium BC (fig. 3.3). The watercourses here are mostly small and seasonal. These areas, however, are often rich in springs. In the more rocky parts water can often been found at a depth between 2.00 and 4.00 meter in subterranean water veins (Italian: falde freatiche) in the karstic base rock.

The remaining parts of southeast Italy are hilly or mountainous. The landscape in the southern coastal strip of the region of Basilicata is somewhat undulating having gently sloping hills close to the beaches. It is the area where the wide and mostly shallow rivers called Agri, Sinni, Brádano and Basénto that rise in the highlands of Basilicata, discharge into the Gulf of Taranto. In this coastal area wide river valleys alternate with the lowly hills (fig. 3.4). It is especially on the latter that the pre-Roman sites are located. Except for the sandy beaches and the narrow strips along the rivers, this area with its calcareous clayey sands is very fertile indeed. These were the fat lands around Siris (or: the river Siris) that were praised by the 7th-century BC Greek poet Archilochos in one of his songs. It is relatively easy to penetrate the interior by following the rivers upstream. As one travels inland, hills gradually turn into mountains. In the western and northern parts of inland Basilicata the mountains are up to 1.400 or $1.500 \mathrm{~m}$ high. The pre-Roman sites in this district are often situated on relatively flat mountain tops (fig. 3.5). Some of these are at an altitude of even more than $1.000 \mathrm{~m}$. From these elevated spots they overlook large parts of the region, especially the lower lying areas towards the coast. The mountains of inland Basilicata have often served as summer pastures for sheep, whilst agriculture is possible in the same inland area by cultivating the terraces at lower altitudes which surround the valley floors.

While north- and south-Apulia have fertile plains, central Apulia is mostly rocky. Here the old and eroded limestone massif of the Murge dominates the landscape (fig. 3.6). It is oriented northwestsoutheast and stretches over c. $250 \mathrm{~km}$ from Taranto in the south to the brim of the Tavoliere plain in north-Apulia. In the western part of central Apulia its peaks are between 500 and $700 \mathrm{~m}$ high. The Murge massif declines more or less stepwise towards the Adriatic coast. The watercourses in centralApulia are all seasonal and have worn their way into the limestone base rock leaving now often dry ravines (It.: gravina or lama). Nowadays the district is mainly given to the cultivation of olives, because the calcareous soils are usually fairly thin. In various places, however, there are substantial pockets of fertile earth. Here wheat and other types of cereals are cultivated. The best soils, however, are found on the two lowest and easternmost 'steps' of the Murge, close to the Adriatic Sea. It is in this coastal strip of central Apulia that the large sites of the pre-Roman period are found.

The present-day landscapes of southeast Italy differ enormously from those of the past. Especially in central and southern Apulia coastal erosion has been substantial. It is estimated that in some places c. $50 \mathrm{~m}$ of the low limestone cliffs has been lost here since the first millennium BC. Sacred caves on the coast, now partly under water, suggest that the sea level of the Adriatic has risen between 1.50 and $2.00 \mathrm{~m}$ since the first millennium BC. The sandy coasts of northern Apulia, Basilicata and northern Calabria have sustained considerable accretions by sedimentation: the site of Metapontion, for instance, was on the coast in ancient times and is now approximately $1 \mathrm{~km}$ inland. This phenomenon was at least partly caused by deforestation that was particularly intense in the 4th and 3rd centuries BC and from later medieval times onward. Mountains and hills, therefore, have been affected by substantial erosion.

Understandably, the vegetation of the predominantly manmade landscapes of today differs from that in the distant past. The human presence in the landscape and especially the varying intensities of this presence were important elements of change from the Neolithic period onward. In some periods manmade landscapes replaced the natural vegetation, in other periods wild nature took over the no longer used grazing areas, abandoned fields and settlement areas. Intensive palynological research can reveal these tendencies and enables us to reconstruct the vegetation of the landscapes of various 


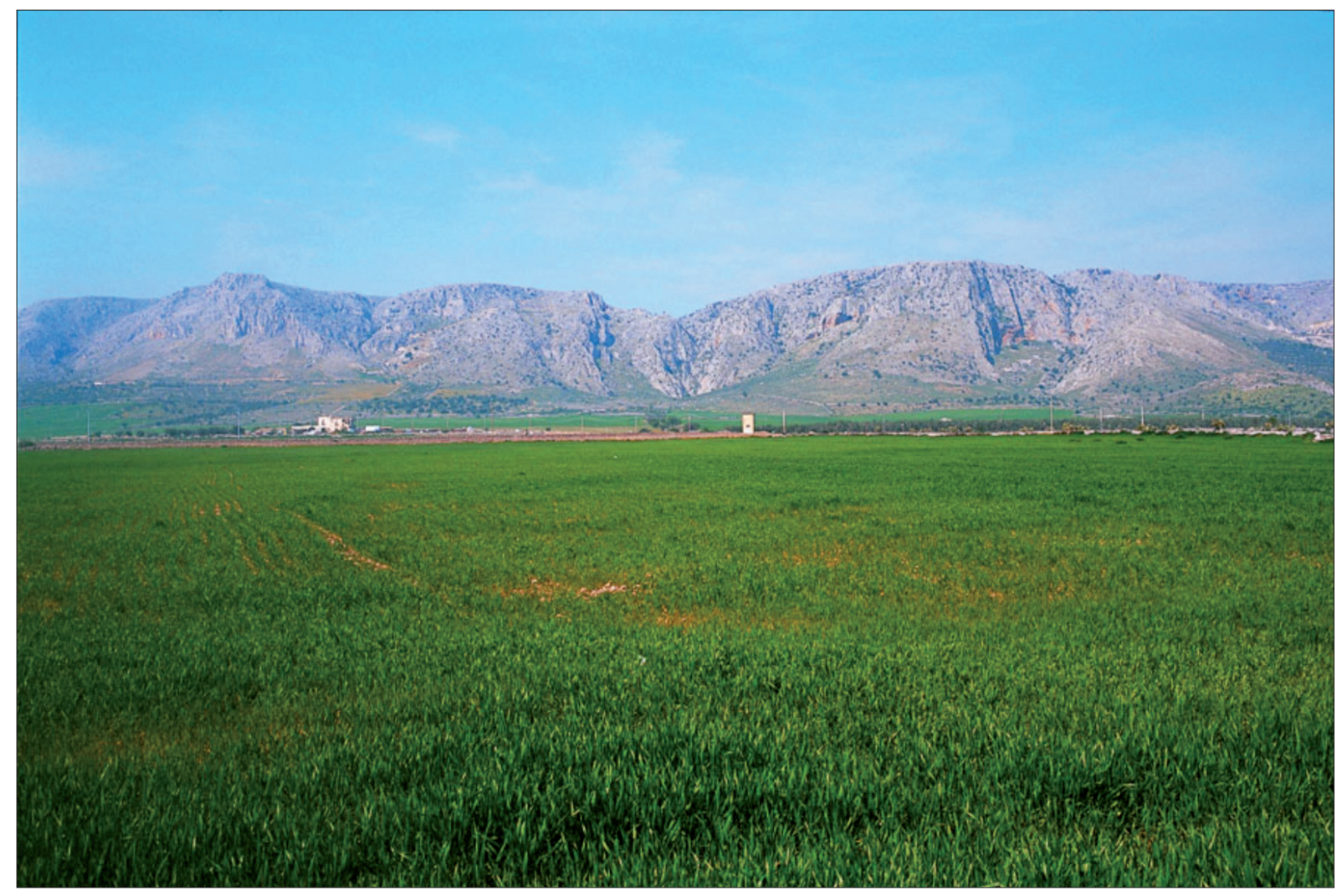

Fig. 3.2. North-Apulia: Tavoliere plain with the Gargano peninsula in the background. Archive ACVU.

moments of the past. In large parts of southeast Italy, however, pollen does not survive. ${ }^{3}$ Reconstruction of the original vegetation, therefore, has been carried out on the basis of patches of the original vegetation that survive in the present landscape. ${ }^{4}$

On the basis of these reconstructions, it seems plausible to assume that before intense human activities changed the environments, large areas of southeast Italy were densely wooded. ${ }^{5}$ Beech (Fagus silvatica) and various types of oak (Quercus) ${ }^{6}$ dominated the forests on the hills and the lower parts of the mountains, while firs (Abies) and various species of pine trees (Pinus) covered the higher parts. The river valleys and the wetlands near the river mouths were the habitat of willows (Salix), ashes (Fraxinus) and elms (Ulmus). Poor and thin soils (especially in central and south Apulia) often sustained a macchia vegetation (French: maquis) consisting of holmoak (Quercus ilex), pines (often Pinus halepensis) and various types of lowly and often spiny shrubbery, but most of the present-day macchia is the result of deforestation and intensive grazing of sheep and goats (fig. 3.7).?

3 For pollen cores from the Laghi Alinini (south-Apulia) see Harding 1999.

4 Veenman 2002.

5 Tichy 1962, Lentjes 2013.

6 The most common types of oak in the forests of southeast Italy were Quercus ilex, Quercus cerris, Quercus petrea and Quercus pubescens.

7 For instance, thyme (Thymus vulgaris), mastic tree
(Pistacia lentiscus), thorny broom (Calicotome spinosa), Spanish broom (Spartium junceum) and rock rose (Cistus monspeliensis). As the human impact on the landscape increased, macchia vegetation extended over larger areas. Much of the present-day 'wild' nature of central and southern Apulia is the result of such human activities in the past. 


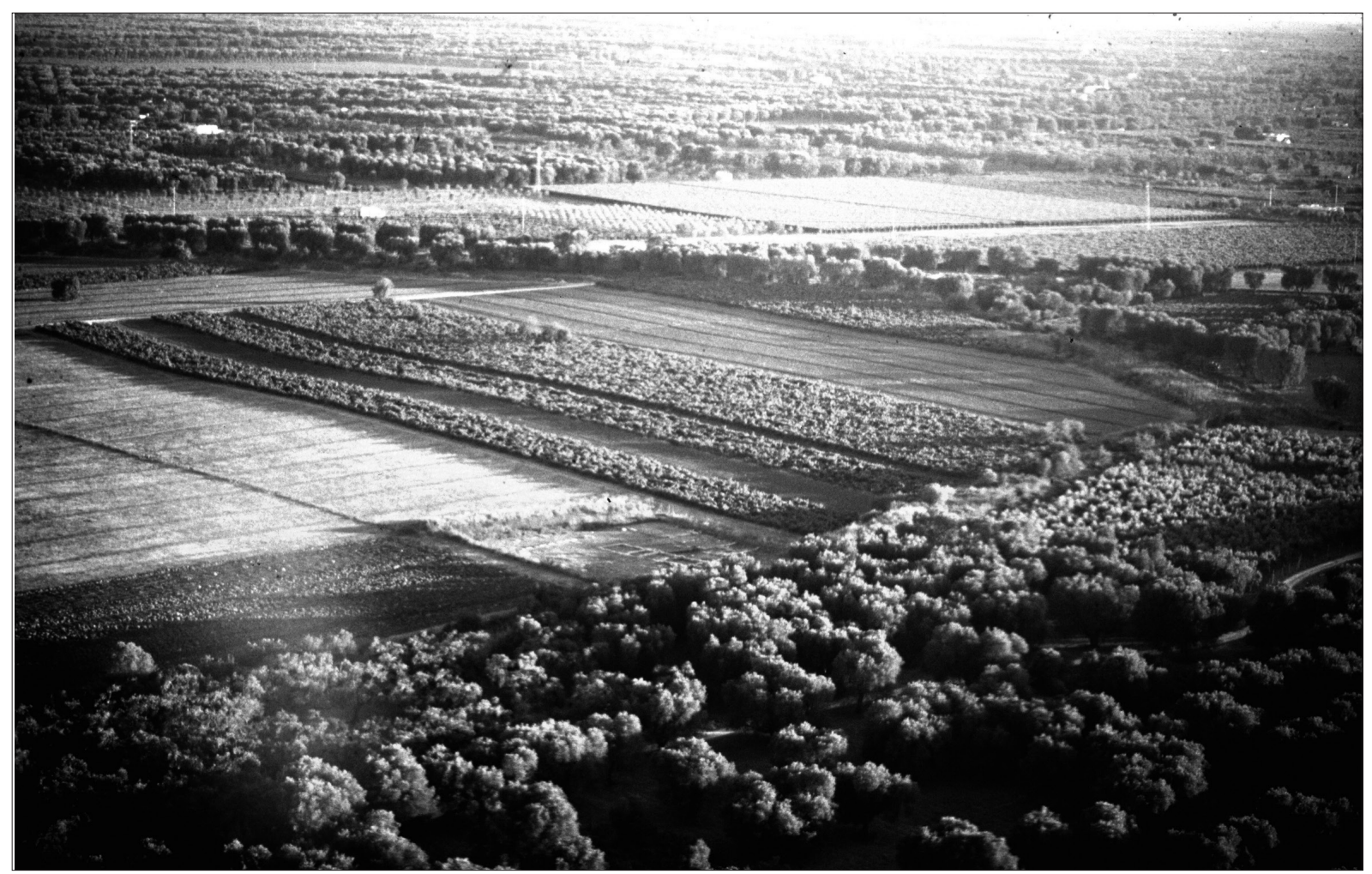

Fig. 3.3. South Apulia: Brindisi plain in the Salento Isthmus. (Pathways, fig. 3.3.). Archive ACVU.

In the preceding chapter we have seen that man's impact on the landscape was considerable as early as the Bronze Age. It was, however, not until the 6th and 5th centuries BC that a first series of very drastic changes took place. ${ }^{8}$ Archaeological field surveys indicate that from this moment onward the human presence in the landscape and the human impact on the natural environments began to take on an unprecedented and rapidly increasing intensity. The human infill of the landscape and the replacement of natural environments by man-made landscapes peaked in pre-Roman southeast Italy in the 4th and 3rd centuries BC. The impact of human activities on the environment seems to have decreased very gradually in Roman times when southeast Italy became a quiet backwater of the Empire. Areas that were rich in water soon became unattractive for human settlement, because a virulent form of malaria ('bad air') became endemic in Italy from the 2 nd century AD. ${ }^{9}$ With the decline of pan-Mediterranean trade systems in late antiquity southeast Italy again became important to Rome. Whilst Apulia produced substantial surpluses of corn, ${ }^{10}$ Lucania (the Roman name for Basilicata) became synonymous with pork. ${ }^{11}$ The presence of large herds of swine in late-Roman Basilicata suggests that substantial parts of the landscape were (again?) densely wooded, since these pigs grew fat on acorns and beechnuts.

In general, the climate in southeast Italy is typically Mediterranean: hot summers with little rain, mild winters with ample precipitation. In fact, in both Basilicata and Apulia most of the rain falls between December and March. The annual quantity of precipitation fluctuates between 600 and $900 \mathrm{~mm}$ (Colamonico 1960; Rossi Doria 1963). However, the winters in these regions of Italy are not particularly mild. The reason for this is that southeast Italy is open to the east and closed off from the west by the Apennines. The region can easily be reached by northern and eastern winds from the Balkans

McNeil 1992.

$9 \quad$ Bruce-Chwatt / De Zuleta 1980, Sallares 2002.
10 Yntema 1993, 224.

11 Whitehouse 1983. 


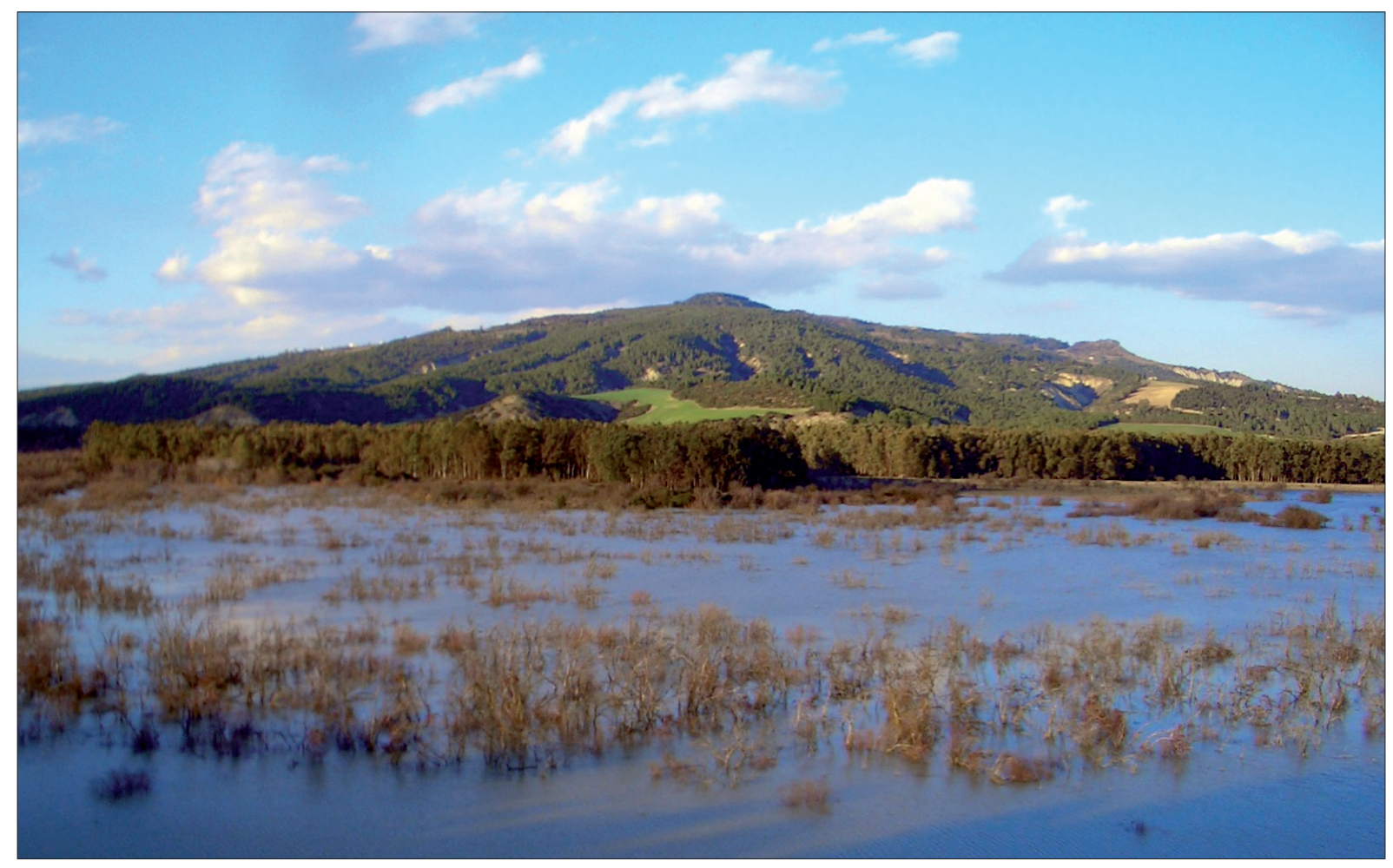

Fig. 3.4. Southeastern Basilicata; basin of the River Bradano and the site of Timmari. Source: www.wikimatera.it.

(in winter the infamous bora), whilst the mitigating influence of Atlantic air masses that commonly is experienced in Tyrrhenian Italy, is basically absent. The winters, therefore, are colder and the summers are somewhat hotter than in Tyrrhenian Italy. The uplands of Basilicata have, of course, a mountain climate. The summers here are relatively cool, whilst the pre-Roman sites at altitudes of 800 to 1.000 $\mathrm{m}$ must have been bitterly cold in winter. Precipitation here is more abundant than in the lower parts of southeast Italy with an annual maximum of c. $1.200 \mathrm{~mm}$.

Climatic changes over the past five or six millennia are documented only in a very general way. However, for people living in the past the microclimate of their particular district was very important indeed. This may change fairly rapidly and may also depend on more or less drastic human actions in the environment such as deforestation and siltation of river mouths and lagoons, the latter usually being the result of anthropogenic changes in the landscape. But these micro-climatic changes are usually not documented. This observation holds good for all districts of southeast Italy. It is, however, believed that the present-day climate of southeast Italy does not differ much from the climate in the first millennium BC.

Communications within pre-Roman southeast Italy were relatively easy, since many parts of this large area have gentle slopes. As we have seen above, almost inaccessible mountain zones are exclusively found in western and northern Basilicata and in northern Calabria. Elsewhere the mountains hardly rise above $500 \mathrm{~m}$. Of course, dense vegetation could be an obstacle to travellers. This may have occurred in macchia areas. A large part of the woods and forests of southeast Italy, however, had a decidedly open character. Red deer (Cervus elaphus) which are commonly encountered in the bone samples from the Bronze Age to well within Hellenistic times, prefer this particular type of open habitat. Travelling though the woods, therefore, was certainly not impossible in the first millennium BC. 


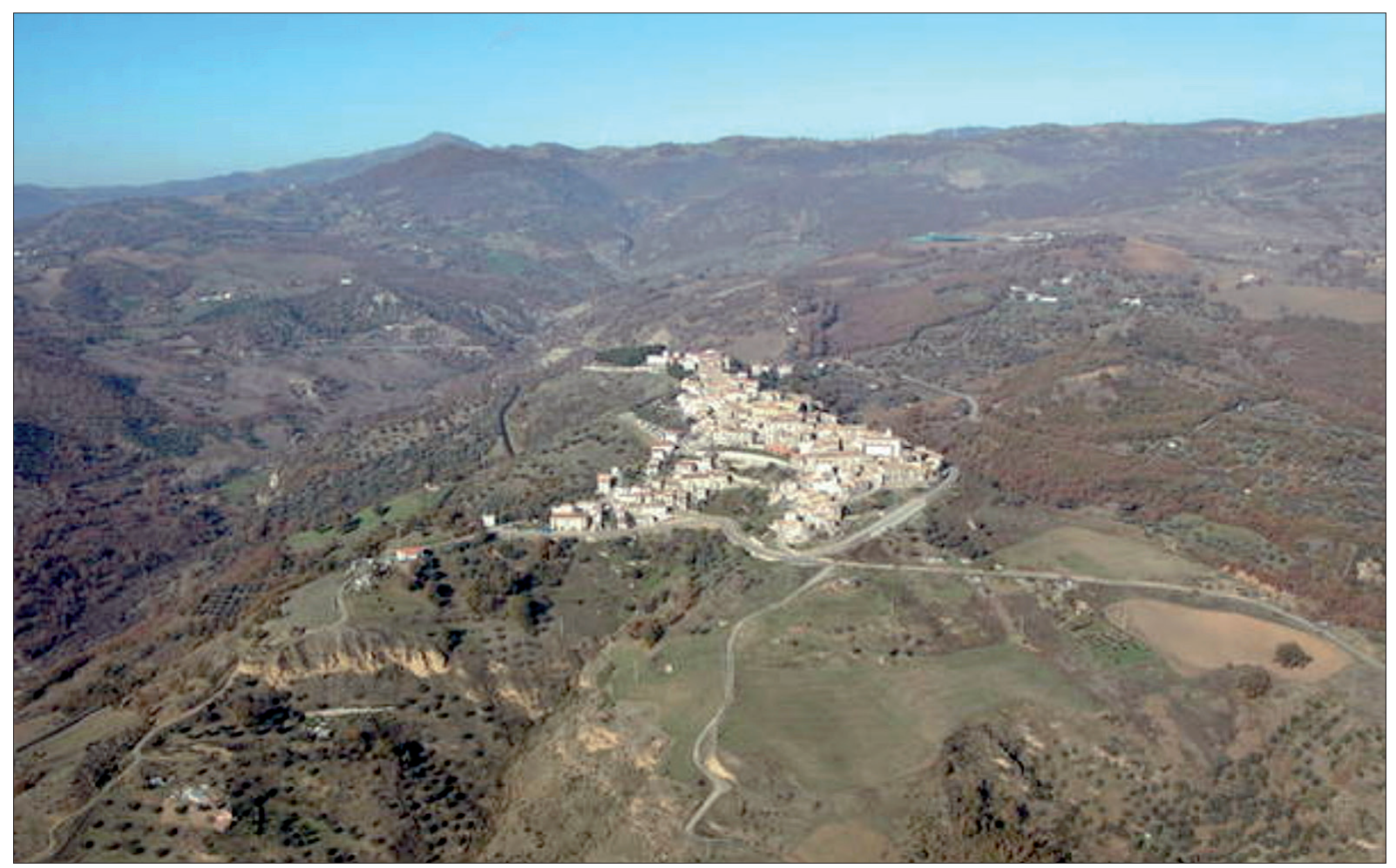

Fig. 3.5. Upper Basilicata; Mountains with the site of Guardia Perticara. Photo: courtesy Basilicata tourist office.

The location of sites is probably indicative of the ancient road systems. Settlements may have originated near river crossings and crossings of long-existing tracks. Roads doubtless linked these, and did so in a more or less direct way. Since many settlements were on or near the coast, important communication took place along coastal routes (either by land or over sea). This holds good for both Basilicata and Apulia. The inland areas of Basilicata could be reached by following the numerous rivers upstream. These descend in a gentle way from the uplands to the lowlands without substantial falls. Many sites in this area are only a few kilometres from the river and could be reached fairly easily in this way. ${ }^{12}$ The same travelling strategy could be applied in the plain of northern Apulia; here the most important sites are actually on the rivulets intersecting the great Tavoliere plain. ${ }^{13}$ In central and southern Apulia watercourses are almost completely absent. Here roads followed the coast, but also bridged, for instance, the isthmus between Taranto and Brindisi. ${ }^{14}$ Since the Salento peninsula in southern Apulia was relatively flat, it offered no major obstacles to communication.

The overland contacts between southeast Italy and other Italian regions were often less easy. The passes leading from Basilicata to Campania are not numerous and are mostly snowed up in winter. Important passages are the c. $1.000 \mathrm{~m}$ high Sella Cessúta linking the basin of the Lucanian river Agri with the basin of the Campanian rivers Sele, Tánagro and Calóre, and the nearly $900 \mathrm{~m}$ high Sella di Conza between the Basénto river system in Basilicata and the Apulian/Campanian Ófanto basin. Northern Apulia was linked to Campania by the almost $800 \mathrm{~m}$ high pass near Ariano Irpino between the Apulian Cerváro river and the Voltúrno-Calóre river basin in northern Campania (fig. 3.1).

12 Adamesteanu 1983.

$14 \quad$ Uggeri 1983.

13 Alvisi 1962. 


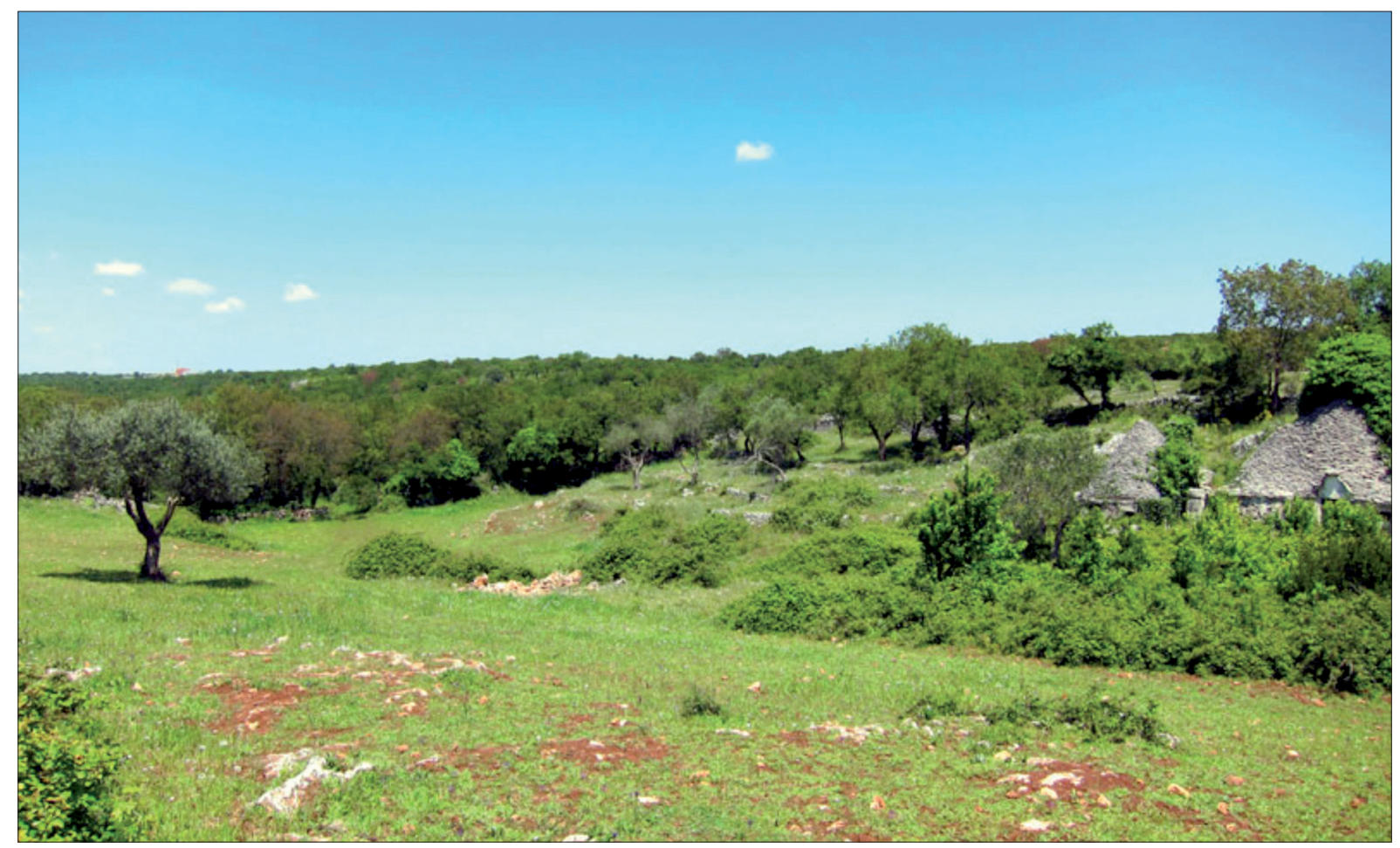

Fig. 3.6. Central Apulia: landscape in the Murge hills with olive trees and limestone with thin cover (ACVU archive).

The seas have always been both obstacles and highways and separated and linked people at the same time. Winds and waves were potentially dangerous, but whilst the land was subdivided into polities and territories, the sea was and is basically the realm of the skipper. Moreover, in pre-industrial societies overseas transport had enormous advantages over land transport. Land transport (e.g. with mules/ donkeys or ox carts) was invariably slow in ancient times. Each cart or animal could transport only a limited quantity of load. For overland transport in bulk animal trains were needed. By sea, however, substantial quantities of bulk commodities could be transported relatively quickly over larger distances.

The seas surrounding southeast Italy were no exception to this general rule. The Adriatic linked southeast Italy with coastal regions of central and northern Italy and with the Istrian and Dalmatian coasts. The best season to cross the Adriatic from Apulia towards Dalmatia was spring with its prevailing southeastern and southwestern winds. The Ionian Sea was the highway from western Greece to southern Italy. In overseas ventures the Strait of Ótranto was important, especially in the first half of the 1st millennium BC. Here the distance between the Balkans and Italy is only $70 \mathrm{~km}$. The passage from the island of Corfu to the heel of the Italian boot, therefore, can be made without loosing sight of the coast. The Strait of Ótranto was Greece's entrance to the western Mediterranean (and to the Adriatic) and Italy's gateway to areas in the eastern part of the Mediterranean. The Gulf of Táranto under the Italian boot linked the coastal settlements of southeast Italy and gave an easy access to the southern parts of present-day Calabria. From here one could sail to Sicily and - by way of the Strait of Messina - towards the Tyrrhenian Sea.

These sea-lanes were all used. This happened in a fairly intense way from the Bronze Age onward (see preceding chapter). There may have been a dip in transmarine contacts between 1100 and 900 BC. These contacts however, were soon resumed. As we will see in chapter 4, there are dozens of pieces of 9th- 8th-century Albanian wares at the south-Apulian site of Ótranto, whilst thousands of Late and Sub-geometric Greek fragments were found in many sites of southeast Italy, and hundreds of 


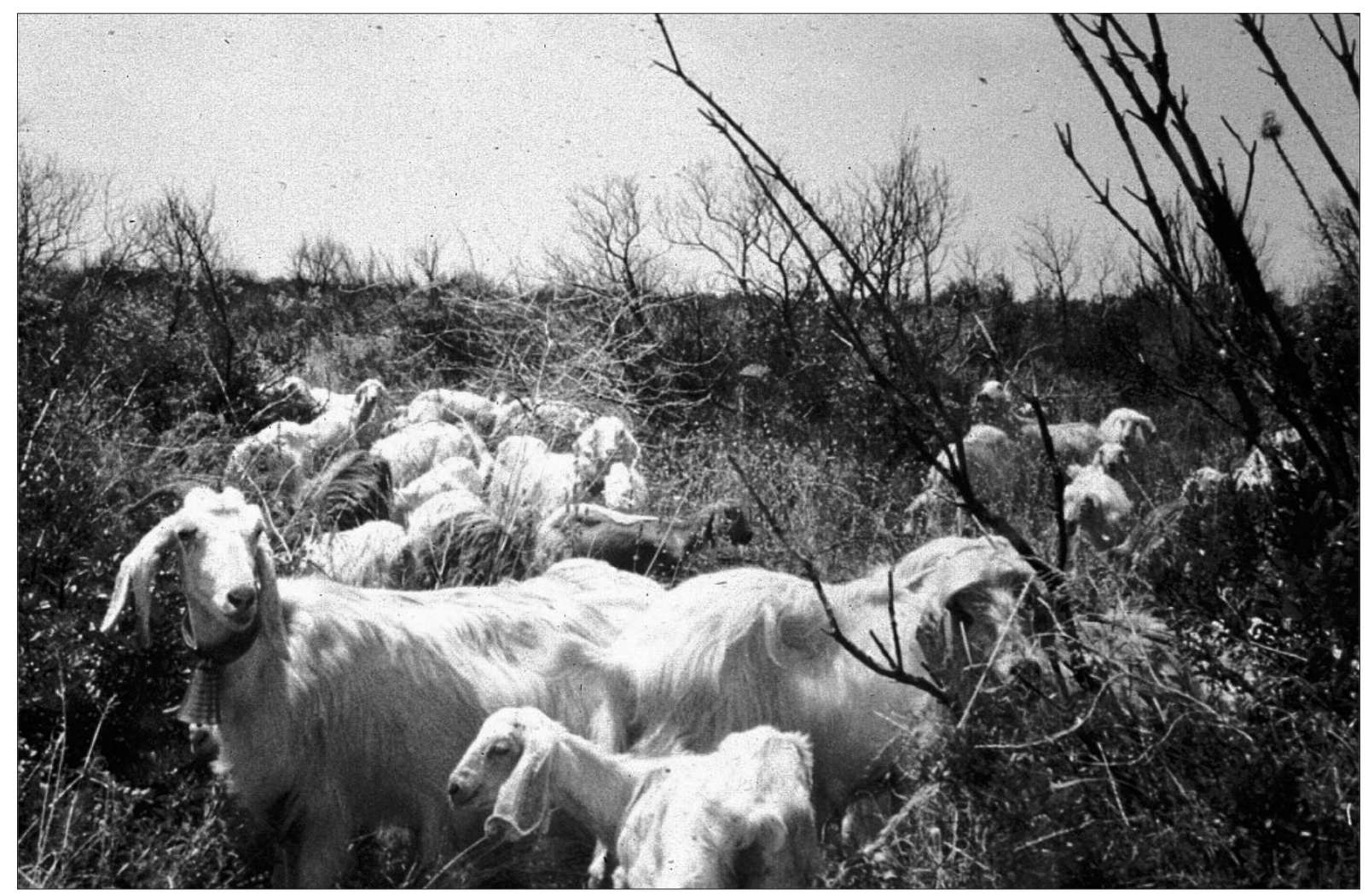

Fig. 3.7. Grazing goats in macchia vegetation. Photo: courtesy Froukje Veenman.

pots and sherds of 8th- and 6th-century north-Apulian wares in the Italian area around Ancona and in the former Yugoslav regions of Dalmatia, Istria and Slovenia.

\subsection{THE PEOPLE OF THE PAST}

The people who inhabited southeast Italy in the 1st millennium BC are currently divided into two large groups: Greeks and non-Greeks. The latter are also indicated by the terms 'natives', 'Italic' or 'indigenous' populations. In both ancient and modern writings these groups are often clearly opposed. This Greek-indigenous dichotomy, however, is at least in part a modern construct that was caused by the rhetorical passages of ancient Greek writers where the Greek 'us' is antithetic to the non-Greek 'others'. In practice this seemingly strict 'ethnic divide' was much more fluid than the Greek written sources suggest. The south-Italian Greeks believed themselves to be immigrants coming from Aegean Greece and lived in a new Greek world that was sometimes indicated as 'Great Hellas' (Megalè Hellas, Magna Graecia). ${ }^{15}$ The majority of these Greeks of southeast Italy lived in four towns (poleis) and their territories (the so-called chorrai), situated in the coastal strip on the Gulf of Táranto. These were Sybaris (later: Thourioi, Roman Copia), Siris (later Herakleia in Lucania), Metapontion (Roman Metapontum) and Taras (Roman Tarentum, now Táranto). They were all considered to be apoikíai ('homes away from home'; i.e. Greek settlements in an originally non-Greek world). In the scholarly tradition of the late 19th and 20th centuries these migrant settlements have been regularly inferred to as 'Greek

15 Cf. Megalè Hellas. Nome e immagine, Atti del ventunesimo

Taranto 1982.

convegno sulla Magna Grecia, Taranto, 2-5 ottobre 1981, 
colonies'. They were states of the 'classic' Greek model of the city state and could have oligarchic, aristocratic or democratic forms of government. In pre-Roman southeast Italy Greeks could also be encountered in non-Greek polities. Both the ancient written sources and the archaeological evidence suggest that sometimes Greeks lived and worked in non-Greek settlements, albeit on a limited scale.

These south-Italian Greeks spoke dialects derived from 'old' Greece and listened to the traditional Greek songs composed, for instance, by Homer. They contributed to Greek literature by writing Greek verse and Greek prose. Furthermore, they worshipped gods with Greek names and participated in the great athletic games of the 'motherland'. They had sets of values and notions that were more or less comparable to those found in Aegean Greece and shared views on their own Greek ambiances and non-Greek other-worlds with the inhabitants of other Greek polities. They were evidently a part of the Greek world that believed to have its core area around the Aegean Sea and that, by the 6th century $\mathrm{BC}$, was dispersed over much of the Mediterranean coastline: the archaic Greek trade diaspora.

The Greek poleis of southeast Italy (and in fact all Greek apoikiai) had a strong mental link with the original core area by means of the metropolis (the 'mother town'). This was the settlement from which the first colonists under the guidance of the founder (oikistes) were believed to have set out in order to found a new settlement 'away from home'. These ties were recorded in the settlement's origo myth. This was often a standard story that recorded the reasons for the venture, the name of the founder (oikistes), the divine sanction given to the undertaking by the Delphi sanctuary, the adventures and misfortunes of the colonists and the actual foundation of the new settlement (ktisis). ${ }^{16}$ The Greek apoikíai, therefore, were very much part of the ancient Greek world.

It is, however, quite probable that the inhabitants of the Greek-speaking settlements of southeast Italy did not usually parade themselves as Greeks. The ancient written sources suggest that their local identity was most important to them. They considered themselves above all as the people of Sybaris (Sybaritai), the people of Siris (Sirinoi), the people of Metapontion (Metapontinoi) or the people of Taras (Tarantinoi). Their loyalties primarily lay with their south-Italian hometown and its territory. Being 'Hellenes' did not mean much to them. In fact, the Greek poleis of southern Italy fought each other in bitter conflicts. As a result of these, two of the four poleis on the Gulf of Taranto (i.e. Sybaris and Siris) lost their status of independent city states in the 6th century BC (see chapter 4$) \cdot{ }^{17}$ Although these Greek city states of southeast Italy were surrounded by non-Greek polities, they cooperated only when external factors forced them to do so. This sometimes happened indeed from the late 5th century onward. The ancient written sources concerning their histories, however, suggest that even in times of substantial external stress caused by non-Greek polities, the regional label of Italiotai ('South-Italian Greeks') was no strong cohesive. Just like the term Sikeliotai ('Sicilian Greeks'), the world Italiotai was basically a term used by non-Italic Greeks to label the Greeks of southern Italy. On occasions (especially in later 4th and early 3rd centuries BC) the term could also be a convenient political instrument in regional politics and served in the often feeble and usually unsuccessful attempts to forge coalitions between Greek towns of southeast Italy in order to withstand outsiders, such as Lucanians or Romans. ${ }^{18}$ In this respect the Greeks of Megalè Hellas were not really different from the Greeks of Hellas.

Indigenous Italic populations inhabited by far the largest part of southeast Italy and basically lived in all the areas that were outside the chorrai (territories) of the Greek towns. Their societies are commonly believed to have had tribal forms of socio-political organization. There is little information about people with indigenous backgrounds living in the four Greek poleis of southeast Italy. Ancient

16 Docherty 1993.

17 They continued to be inhabited and regained their polis status in the 5th century BC when Sybaris became the polis of Thourioi and Siris became Herakleia in Lucania.

18 For the use of the term Italiotai, see Lomas 1993; for the use Sikeliotai, see, for instance, Antonacci 2001. 
written sources on similar Greek towns on the Tyrrhenian Sea such as Naples and Paestum suggest that the presence of people with non-Greek roots in Greek towns was a rather common phenomenon. The Greek city states of southern Italy may have been less restrictive - at least at some stages of their history - in assigning citizen rights to persons with non-local backgrounds than most Greek poleis in Aegean areas.

For southeast Italy the term 'natives' or 'indigenous (Italic) populations' is an even more gross oversimplification than the term 'Greeks'. It has been adopted by both archaeologists and ancient historians in order to label non-Greek groups of pre-Roman Italy. We have seen above that the terms 'south-Italian Greeks' or 'Italiotai' probably did not correspond to any identity perceived by the Greekspeakers of southeast Italy themselves, or did so only on rare occasions. The same observation holds good for the various names for indigenous populations of southeast Italy given in the ancient written sources. These were basically labels used by outsiders such as Greeks and Romans for Italic groups for whom Greek and Latin were foreign languages. In northern Calabria and large parts of Basilicata, for instance, Oscan dialects were used both in daily life and in official documents. ${ }^{19}$ These belonged to the Osco-Sabellic language group that is fairly close to Latin. In present-day Apulia the Messapic language was widely spoken which, being of the Illyrian branch, differed vastly from Oscan. ${ }^{20}$ The only surviving example of this language group is present-day Albanian. Illyrian languages were widely spoken in the coastal region of Croatia and Montenegro to well within Roman times.

Each of these two large language groups of southeast Italy is likely to have contained several sociopolitical groups. Since these Italic groups left no written texts in which they label themselves, we have to depend on the ancient Greek and Latin written sources and the archaeological data. However, we shall see below that both types of sources are not really helpful in identifying non-Greek socio-political groups. The non-Greek groups of southeastern Italy have also left no writings documenting their views on their past and present. What we believe to know about their inhabitants has been written down by Greeks and Romans or excavated by archaeologists. The ancient authors, however, because of the opposition created by the rhetoric of the Greek versus barbaros stereotype, cannot be considered as reliable sources on all things native. The Greek custom of lavishly and uncritically citing earlier authors causes additional problems. Pieces of information often referring to various moments in time tended to blend into one single image in the works of the relatively late compilators whose works have survived. ${ }^{21}$ This is especially problematic for the tribal world of southern Italy, since tribal societies are fairly unstable political units and subject to sudden and rapid changes in their socio-political structure. ${ }^{22}$

From the 6th century BC onward ancient Greek authors identified and labeled the indigenous populations they encountered in southern Italy. The names they gave them are, of course, patently Greek labels and do not necessarily represent socio-political entities as perceived by the indigenous groups of southeastern Italy themselves. Some of these Greek labels, moreover, changed in the course of time. This may be the result of either the dynamic nature of the indigenous tribal societies of southern Italy or changed perceptions of Italic groups among the Greek groups of southern Italy.

However, the Greek writers whose texts have survived were not really informative on their Oscan and Messapic speaking neighbours. ${ }^{23}$ They tell us something about the origins of the tribes (be it

19 For such official documents, see the so-called Tabulae Bantinae which contain parts of a lex in Oscan from the site of Banzi (Roman Bantia) in northeast Basilicata. The Oscan inscriptions of Basilicata-Lucania have been collected in Del Tutto Palma 1990.

20 For Messapic inscriptions, see De Simone / Marchesini 2002.

21 For instance, Strabo's Geography; cf. Laserre 1967.
22 The substantial differences between the Gallic tribes described in Caesar's De Bello Gallico and those found in the Julio-Claudian period is a good example of dynamic nature of tribal structures.

23 The ancient written sources for the south-Apulian Salento peninsula have been collected by Lombardo (1992); for the ancient written sources on central Southern Italy, see Cordano 1971. 
either real or perceived), but mainly inform us on the great victories Greek-speakers of southern Italy gained over the indigenous tribes and painful setbacks suffered by the Greeks poleis at the hands of non-Greek groups. These written sources, moreover, indicate where approximately the people lived that the Greeks identified as a more or less coherent group. This ethnic labeling, however, is very confusing, since - as we have seen above - several subsequent chronological layers may have merged into one single picture. Such passages have been subject of much learned debate in order to restore the 'stratigraphical sequence' of such terms. ${ }^{24}$ It is, however, uncertain whether these tribal names supplied by ancient Greek authors, bear any relationship to tribal realities of the pre-Roman past. They can be characterized as the Greek labels for tribal groups as perceived by Greek poleis dwellers.

With these caveats in mind the most frequently used terms and names concerning the south-Italian indigenous world may be given here. In the 6th century BC the Greeks probably discerned two large groups in the districts under discussion. The Iapyges predominantly lived in present-day Apulia and the Oinotrioi (also Opikoi, and Chaones) in present-day Basilicata and northern Calabria. ${ }^{25}$ Since the differences in material culture were not particularly impressive, language may have been an important discriminating factor that induced Greeks to make this subdivision: the Oscan language of the Oinotrioi of Basilicata and northern Calabria against the Messapic language of the Iapyges in Apulia. According to the ancient authors, however, this latter region was also inhabited by other tribes which were probably considered to be subdivisions of the Iapyges. The Daun(i)oi are believed to have lived in the far north of Apulia (Tavoliere district and Ofanto area), the Peuketioi (also 'Poidikloi') in central Apulia and the Messapioi (in the southern Salento peninsula). ${ }^{26}$ Whilst the Greek denominations of the groups in present-day Apulia did not change much, ${ }^{27}$ the labels Opikoi, Oinotrioi and Chaones became obsolete in the course of the 5th century BC. From about the middle of that century, the new label 'Lucanians' seems to have replaced these.

As we have seen above, it is highly questionable whether all these Greek labels actually represented native socio-political realities as perceived by the non-Greek, indigenous groups themselves. These same Greek labels, however, have been applied by modern authors to the characteristic material culture assemblages of the various districts of southeastern Italy. ${ }^{28}$ These are indicated here with the term 'cultural groups' since the traditional approach to the archaeology of southeast Italy was basically founded on V. Gordon Childe's concepts of 'culture' and 'cultural groups'. ${ }^{29}$ This term can be defined here as: a series of settlements within a well-defined, geographical district displaying a set of shared cultural features (usually over a prolonged period) that is characteristic of that particular district only.

By now it is generally acknowledged that cultural groups identified by archaeologists do not necessarily coincide with self-defined socio-political groups. As for southeast Italy, in some cases the ancient Greek term corresponds with a regional cultural group identified by archaeologists, in other cases it certainly does not fit the artefactual evidence as interpreted by archaeologists. In fact, more cultural groups have been discerned than there are Greek names for indigenous tribes. These basically Greek

24 Panebianco 1972; Nenci 1978.

25 For the area of the Iapyges, see Nenci 1978; for the Oinotrioi, see Kilian 1964, 131-133 and Panebianco 1972.

26 There are many views on this matter. The relationship between Oinotrians and Chaones (or Chones) is, for instance, unclear. It is uncertain whether the Greeks saw the Oinotrioi and the Chaones as two different groups or whether they saw the Chaones as a subgroup of the Oinotrioi. The term Iapyges was sometimes applied to two of the three Apulian groups only, i.e. those of north and central Apulia.

27 From the late 4th or 3rd century onward Greeks and Romans mention two groups for the southApulian Salento district (Calabri and Sallentini in addition to the possibly more general denomination Messapioi or Messapii).

28 Mayer 1914; De Juliis 1988.

29 Childe 1929. 
terms - however incorrect they may be - are widely accepted and commonly used. It would, therefore, be rather foolish to replace them by new, more correct terminologies.

In southeast Italy eight cultural entities can be discerned during the Iron Age (the archaeological' geography). Each of these corresponds to a well-defined geographical area, mostly with natural boundaries. These eight districts - each with its own characteristic cultural assemblages - are described below. The list of sites given for each district contains a selection of settlements (fig. 3.8):

The Crati district: the northern part of present-day Calabria consisting of the plain of the rivers Crati and Coscile and the foothills of the surrounding Pollino and Sila mountains. In the Italian archaeological reports the area is often indicated as the Sibaritide, i.e. the area around the settlement of Sybaris. The principal sites here are Sybaris (later: Thourioi or Copia) and Torre del Mordillo. This part of southeastern Italy has only recently been identified as a distinct district. The most commonly used term for its indigenous inhabitants is 'Oinotrians'. From the later 5th century BC the terms 'Lucanians' or 'Brettians' are used for the inhabitants of this district.

Pre-Roman settlements of the same district: Francavilla Marittima, Amendolara, Trebisacce, Castrovillari and San Sosti.

The Agri-Sinni district: the western parts of Basilicata and adjacent areas of southern Campania; the district is made up of the basins of the rivers Agri and Sinni with their gently sloping hills. In Italian archaeology the area is commonly referred to as the Siritide, i.e. the district that is considered to be the hinterland of the settlement of Siris/Herakleia. Important sites in this area are Siris/Herakleia, Santa Maria d'Anglona, Alianello and Chiaromonte. The indigenous groups of this area have been labeled as 'Oinotrians' or 'Chaones'. From the later 5th century BC onwards the indigenous population of this district goes by the name of the Lucanians.

Pre-Roman settlements of the same district: Craco, Armento, Roccanova and Sala Consilina.

The Bradano-Basento district: the eastern parts of Basilicata and the western fringes of present-day Apulia: the district consists of the basins of the lower Basento and Bradano with their gently sloping hills. The district is indicated in archaeological reports as the Materano or the Metapontino, i.e. the area around present-day Matera or the district that is believed to be the hinterland of ancient Metapontion; important sites here are Metapontion, l'Incoronata di Metaponto, Montescaglioso, Timmari and Monte Sannace. The non-Greek populations of this district are mostly indicated as 'Oinotrians' in that part of the district that is in the present-day region of Basilicata, while the sites in the present-day Apulian province of Bari are often indicated as 'Peucetian'. Whether this district was perceived by the Greeks as a Lucanian area from the 5 th century BC onwards is uncertain.

Pre-Roman settlements of the same district: Difesa di S. Biagio, Pisticci, Ferrandina, Pomarico Vecchio, Cozzo Presepe, Garaguso, Miglionico, Gravina di Puglia, Altamura, Santeramo in Colle, Ginosa, Palagiano, L'Amastuola.

Upper Basilicata district: the district consists of the mountainous areas of inland Basilicata which control the mountain passes connecting Basilicata with Campania. The district has only recently been identified as a separate cultural entity. Important sites in this district are Serra di Vaglio and Satriano di Lucania (all in Basilicata). The indigenous populations of the area are indicated as 'Oinotrians' or 'Opikoi'. ${ }^{30}$

30 The term 'Opikoi' is often used for the population of the area close to the Greek polis of Elea (Velia) before the middle of the 5 th century BC.. 
Pre-Roman settlements of the same district: Baragiano, Cancellara, Torretta di Pietragalla, Croccia Cognato, Guardia Perticara, Ruvo del Monte, Oppido Lucano, (all in Basilicata) and Buccino (Roman Volceii), Atena Lucana and possibly Roccagloriosa (all in present-day Campania).

The Tavoliere district: the district is made up of the large, north-Apulian plain surrounding the present-day provincial capital of Foggia and the first range of foothills of the Apennines. Relatively well-known sites in this district are Ascoli Satriano (Roman Ausculum), Ordona (Roman Herdoniae), Arpi and Siponto (Cupola/Beccarini). The important, but poorly known site of Monte Saraceno (Gargano peninsula) may well belong to the same cultural group. The indigenous groups of the Tavoliere in pre-Roman times are mostly indicated as the 'Daunians'.

Pre-Roman settlements of the same district: San Paolo Civitate (Tiati, Roman Teanum Apulum), San Severo, Troia (Roman Aecae), Lucera (Roman Luceria).

The Ofanto district: the district consists of the range of hills south of the river Ofanto and is situated in the northern part of the present-day Bari province. Canosa (Roman Canusium) and Ruvo di Puglia (Roman Rubi) were major centers here. Archaeological reports usually refer to the preRoman population as the 'Daunians'. From the 5th century onward Ruvo di Puglia shares many characteristics with the sites in the Bari area.

Pre-Roman settlements of the same district: Salapia (Lupara-Giardino), Barletta, Cannae, Minervino Murge and Lavello (Roman Forentum).

The Bari district: the district consists of a $20 \mathrm{~km}$ wide and 25 to $35 \mathrm{~km}$ long coastal strip of the present-day Bari province, southeast of Bari. Near the coast fertile soils alternate with areas where the base rock comes close to the surface. In the Bari area quite a number of sites are found in the Iron Age. From the 6th century onward it has three large sites: Ceglie del Campo (also: Valenzano; Roman Caelia), Rutigliano/Noicattaro (Roman Azetium) and Castiglione di Conversano. PreRoman settlements of the same district: Bitonto (Roman Butuntum), Bari, Conversano and Adelfia/ Canneto. This district is often indicated in archaeological reports as the area of the Peuketioi. ${ }^{31}$

The Salento district, surrounded by seas on three sides, makes up the heel of the Italian boot. In the hilly northern and southern parts the limestone base rock comes close to the surface. The central area including the isthmus has mostly fertile clayey sands. Traditionally, it is believed to be the district of the Messapioi. From Hellenistic times onward the names of Kalabroi and Sal(l)entinoi are found for people living in the same area. These were possibly subdivisions of the Messapioi, the Kalabroi being the inhabitants of the northern part of Salento, while the name of Sallentinoi was used for those non-Greeks who lived in the southern part of the Salento peninsula. The settlement of Oria (Roman Uria Calabra) was probably the most important settlement in the northern part of the peninsula. Other important settlements here were perhaps Ceglie Messapico, Ostuni and Brindisi. In the central part of Salento Rudiae and Cavallino di Lecce were sites of major importance, whilst Ugento (Roman Uxentum) was almost certainly the most important tribal center in the southern tip of Salento.

Pre-Roman settlements of the same district: Gnathia, Valesio, Muro Tenente, San Pancrazio Salentino, Manduria, Castelli di Manduria, Monte Salete (in the northern part); Lecce, Rocavecchia, Otranto, Vaste, Muro Leccese, S. Maria di Vereto, Monte Sardo (Alessano), Alezio, Fani, Soleto and Nardò (all in the southern part of the Salento peninsula).

31 In several publications the term 'Peuketioi' is used for the indigenous groups of the present day province of Bari (cf, De Juliis 1995). The western fringes of this province including the important sites of Monte Sannace, Altamura and Gravina di Puglia, however, belong to the same cultural group as important settlements of eastern Basilicata/Metapontino district, whilst the northern parts of the same province constitute the core area of the Ofanto district (sites: Ruvo di Puglia, Canosa, Cannae etc.). 


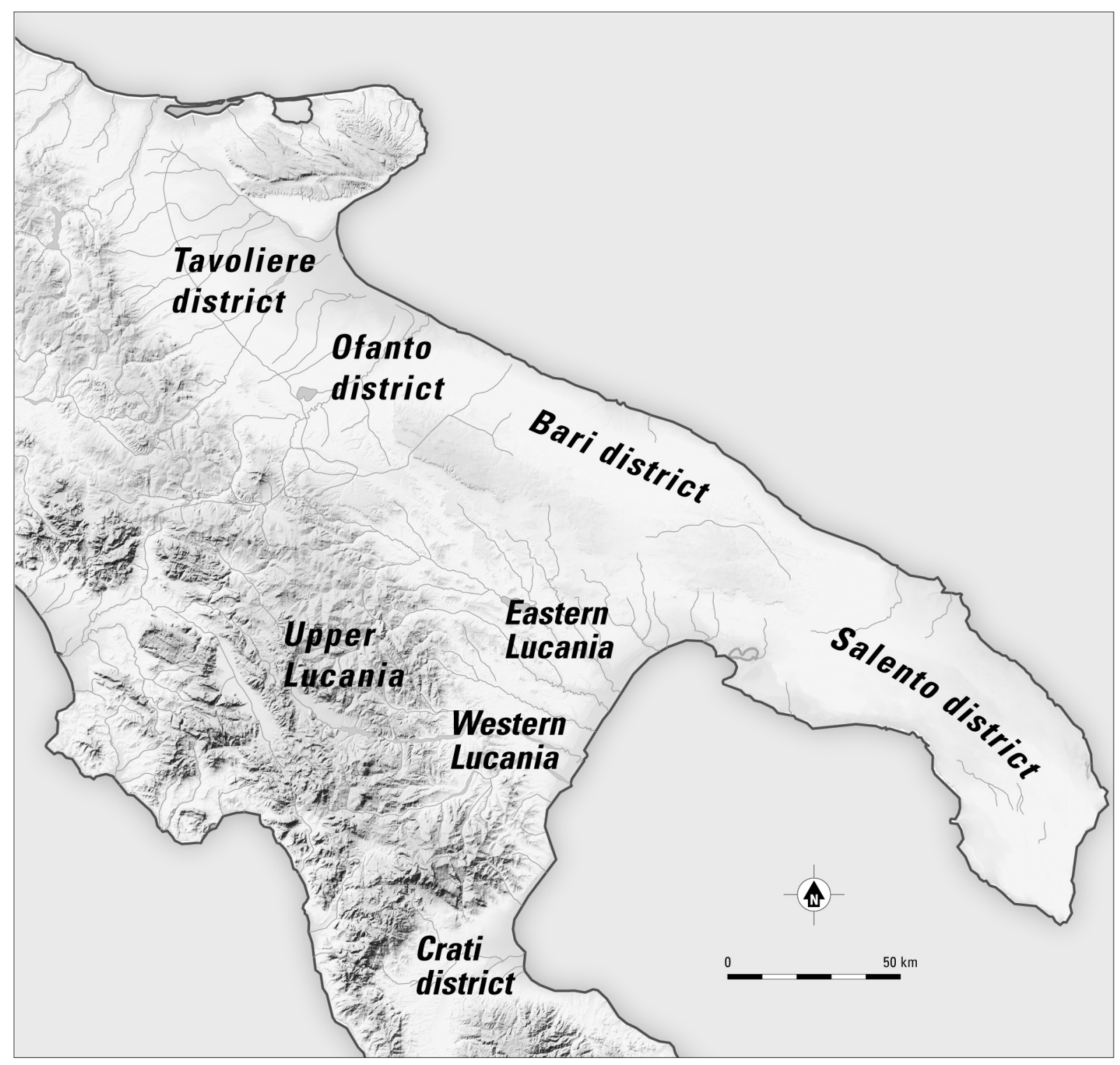

Fig. 3.8. Present-day 'archaeological' geography: districts of southeast Italy with cultural groups identified by archaeologists (situation in the late 6 th/early 5 th century).

These cultural groups as defined above continued to be highly visible all over southeast Italy to within the 5th century BC. From that time onwards the differences between them became less conspicuous, because the material culture of the various non-Greek districts bordering on the chorrai of the Greek city states was rapidly becoming more and more uniform: Greek shapes, ornaments and techniques were widely adopted by the craftsmen of 'indigenous' southeast Italy. This process of artefactual change (often erroneously called 'Hellenization') affected the Sibaritide, Basilicata and south and central Apulia most strongly. The north-Apulian districts which were quite distant from the Greek poleis, retained many of their Iron-Age peculiarities to well within the 3rd century BC. 


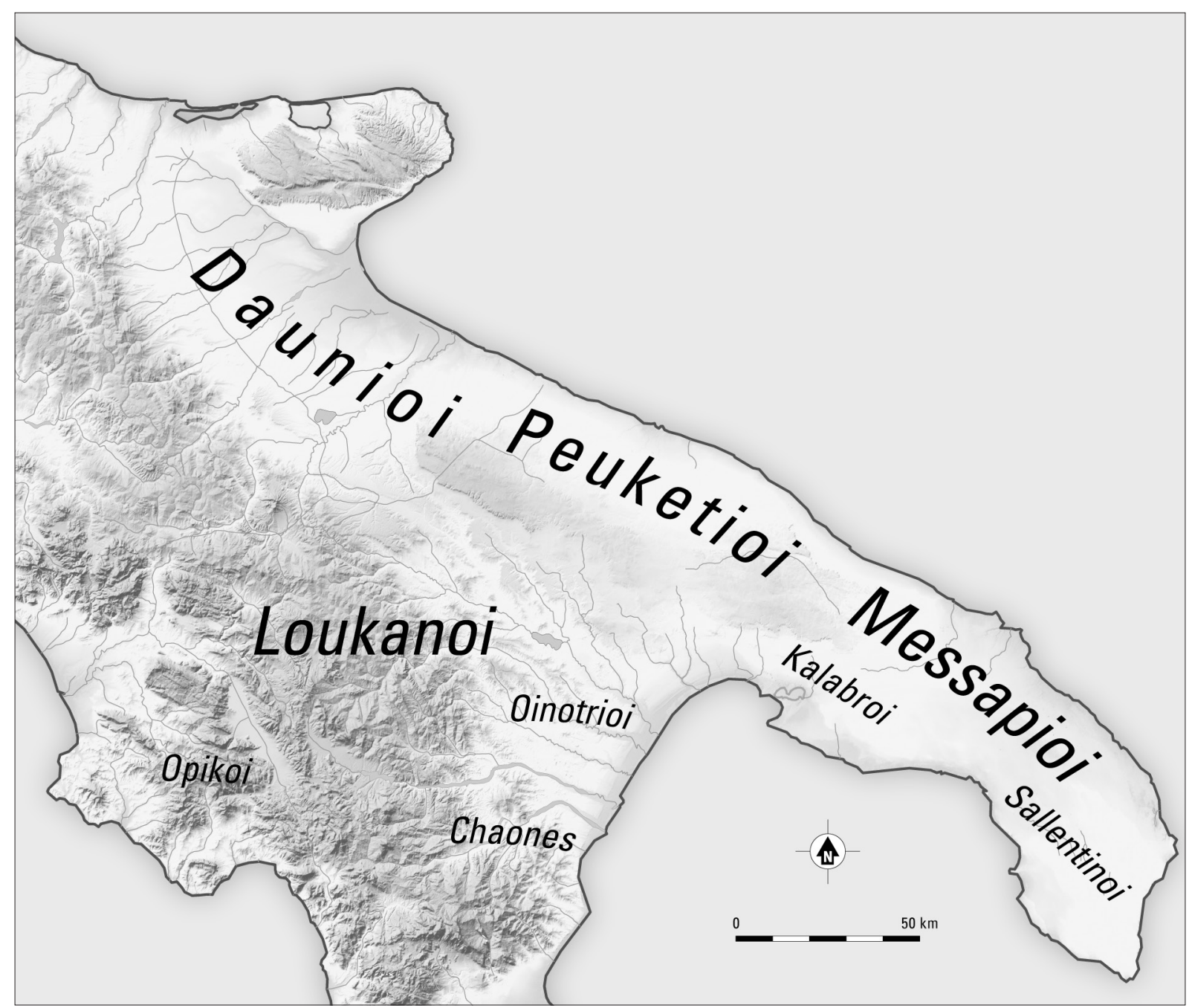

Fig. 3.9. Ancient Greek geography (6th to 3rd century BC): map with tribal names used by ancient Greek authors.

\begin{tabular}{llll}
\hline Districts & $\begin{array}{l}\text { Greek label(s) } \\
\text { VI-V BC }\end{array}$ & $\begin{array}{l}\text { Greek label(s) } \\
\text { IV-III BC }\end{array}$ & Roman label(s) III-I BC \\
\hline $\begin{array}{l}\text { North-Calabria } \\
\begin{array}{l}\text { Basilicata (and } \\
\text { southern Campania) }\end{array}\end{array}$ & Oinotrioi & Loukanoi, Brettioi & Bruttii \\
North-Apulia & Oinotrioi, Chaones, Opikoi & Loukanoi & Lucani \\
Central Apulia & lapyges, Daunioi & lapyges, Daunioi & Apuli \\
Sout-Apulia & lapyges, Peuketioi, Poidikloi & lapyges, Peuketioi & Apuli \\
& lapyges, Messapioi & Messapioi, Kalabroi, Sallentinoi & Messapii, Calabri, Salentini
\end{tabular}

Table 3.1. Greek and Roman labels for indigenous groups living in southeast Italy.

In the following chapters these basically Greek labels for indigenous groups will be used regularly. The ceramics of northern Apulia, for instance, will be indicated as 'Daunian' pottery and a non-Greek town of southern Apulia will sometimes be called a 'Messapian' settlement. It should be noted that within the context of this book the 'terms 'Daunian' and 'Messapian' are exclusively convenient labels in order to denote objects or features characteristic of a specific district of southeast Italy. 